\title{
Impact of different scan strategies and implant angulation on impression accuracy of full arch multiple implant: an in vitro study
}

Impacto de diferentes estratégias de escaneamento e angulação dos implantes na acurácia da moldagem de implantes múltiplos em arco completo: um estudo in vitro

Danilo de Melo LOPES ${ }^{1}$ (), Roger NISHYAMA ${ }^{1}$, Washington STEAGALL JR. ${ }^{2}$, Regina TAMAKI ${ }^{1}$, Pedro TORTAMANO NETO $^{1}$ (1)

1 - Universidade de São Paulo, School of Dentistry, Department of Prosthodontics, São Paulo, SP, Brazil.

2 - Universidade Nove de Julho, School of Dentistry, Department of Restorative Dentistry, São Paulo, SP, Brazil.

\begin{abstract}
Objective: to evaluate the impact of three different scan strategies and implant angulation on impression accuracy of an intraoral scanner for full-arch multiple implant scan. Material and Method: A maxillary edentulous model with six implant analogs served as a reference model. The four anterior analogs were positioned parallel to each other, the distal right and the distal left was placed with an angulation of $15 \mathrm{o}$ and 20o, respectively. Thirty impression were performed using an intraoral scanner (CEREC Primescan). The master cast was digitalized with an industrial reference scanner (ATOS Core 80). All scans were converted to standard tessellation language (STL), superimposed on the reference scan with a 3d inspection software (GOM Inspect Professional 2019) and then analyzed. Results: All linear distances presented equivalence $[\mathrm{p}<0.01]$ to those found on the reference scan for all scan strategies. All scan strategies presented a tendency of negative means for linear distances except for $\mathrm{d} 4$ in strategy C. All angular distances did not present equivalence $[\mathrm{p}=0.05]$ to those found on the reference scan. Significant 3D deviations [p<0.05] were found between strategy B $(0.02 \pm 0.01)$ and C $(0.05 \pm 0.04)$ for $\mathrm{d} 1$. In all others linear and angular distances no statistically significant difference was found between strategies A, B and C. Conclusions: There was no statistically significant difference between strategies A, B and C except for d1 in strategy B and C; Implant angulation did not affect the accuracy of the CEREC Primescan IOS.
\end{abstract}

\section{KEYWORDS}

Precision; Trueness; Edentulous jaw; Dental implant; Dental impression technique.

\section{RESUMO}

Objetivo: avaliar o impacto de três diferentes estratégias de escaneamento e angulação do implante na acurácia da moldagem de um scanner intraoral na moldagem de múltiplos implantes em arco completo. Material e Métodos: Um modelo edêntulo de maxila contendo seis análogos de implante serviu como modelo de referência. Os quatro análogos anteriores foram posicionados paralelos entre si, o distal direito e o distal esquerdo foram posicionados com angulação de $15 \mathrm{o}$ e 20o, respectivamente. Trinta moldagens foram realizadas usando um scanner intraoral (CEREC Primescan). O modelo mestre foi digitalizado com um scanner de referência industrial (ATOS Core 80). Todas as escaneamentos foram convertidas para a linguagem de mosaico padrão (STL), sobrepostas ao escaneamento de referência com um software de inspeção 3D (GOM Inspect Professional 2019) e, em seguida, analisadas. Resultados: Todas as distâncias lineares apresentaram equivalência $[p<0,01]$ àquelas encontradas na escaneamento de referência para todas as estratégias. Todas as estratégias de escaneamento apresentaram tendência de médias negativas para distâncias lineares, exceto para d4 na estratégia C. Todas as distâncias angulares não apresentaram equivalência $[\mathrm{p}=0,05]$ às encontradas no escaneamento de referência. Desvios 3D significativos [p $<0,05]$ foram encontrados entre a estratégia $B(0,02 \pm 0,01)$ e $C(0,05 \pm 0,04)$ para d1. Em todas as outras distâncias lineares e angulares, nenhuma diferença estatisticamente significativa foi encontrada entre as estratégias A, B e C. Conclusões: Não houve diferença estatisticamente significante entre as estratégias A, B e C, exceto para d1 na estratégia B e C; A angulação do implante não afetou a precisão do CEREC Primescan.

\section{PALAVRAS-CHAVE}

Precisão; Veracidade; Arco completo; Implante dentário; Moldagem. 


\section{INTRODUCTION}

Digital impressions present some clinical impacts with respect to conventional impressions, such as lower patient discomfort, time efficiency and simplified procedures for the clinician, especially when multiple implants are present $[1,2]$. Bohner et al. [3] reported the acceptable accuracy of the current scanning technologies for specific applications and this accuracy depends especially on the scanner technology, object shape and scanning strategy. It was also reported, by the authors, the clinical challenge regarding the scanning of the edentulous arch.

The accuracy of an Intraoral Scanner (IOS), as defined by ISO-5725-1:1994, is a combination of trueness and precision. Trueness describes the deviation of scans from the true dimensions of the object, while precision describes how much separate scans of the same object differ from each other [4]. Data from literature indicate that the accuracy of fully edentulous scans is more difficult to be achieved due to the lack of reference points and the distance between the scan bodies (SB) $[5,6]$. Once the virtual model accuracy is affected by the camera movement, the correct scan strategy has an import role on fullarch multiple scan accuracy $[2,3]$. Nevertheless, it remains unclear which is the best scanning strategy of digital impressions [7].

This in-vitro study aimed to assess the impact of three different scan strategies and implant angulation on impression accuracy of an intraoral scanner in a full-arch multiple implants maxilla. The null hypothesis was that there are no differences between the scan strategies and implant angulation for accuracy.

\section{MATERIAL AND METHODS}

\section{Master cast}

A type IV stone master cast (Fujirock; GC America, USA) of an edentulous maxilla with six internal connection analogs (Bone Level NC; Straumann, Switzerland) was fabricated. The median four implants analog were parallel to each other. The distal right was placed with an angulation of $15^{\circ}$ and the distal left of $20^{\circ}$. The master cast scan was obtained with a high accuracy industrial reference scanner (ATOS Core 80, GOM GmbH, Germany).

\section{Scan strategies}

Polyetheretherketone (PEEK) scan bodies (NC scan body; Straumann, Switzerland) were connected to the analogs on the master cast with $10 \mathrm{Ncm}$. Three scan strategies (A, B and C) were used (Figure 1) and ten repeated impressions were performed ( $n=10$ per group) with an intraoral scanner (CEREC Primescan; Sirona, Germany). In scan strategy A, first, the occlusal surfaces were scanned. Second, the buccal surfaces from the distal area toward the middle line. Third, the palatal surfaces moving towards the other side of the arch and lastly, buccal lingual rotation are made on the scan bodies in premolar area. Strategy B started at the distal-palatal surface moving towards the other side of the arch. Second, the occlusal surface and returning via the buccal surfaces. Strategy C started at the buccal surfaces at middle line towards the distal area, for both sides, continuing on the occlusal surfaces and returning on the palatal surfaces. All the scans were performed by the same operator.

\section{Comparative analysis}

In order to calculate the deviations, six linear and two angular distances were set (Figure 2). Reference points were related to the cross-section of the center of the scan body cylinder of the master scan and the experimental scans. STL data from group A, B and C were subsequently superimposed on the reference scan with a $3 \mathrm{~d}$ inspection software (GOM Inspect Professional 2019, GOM GmbH, Germany) using the best fit alignment to assess the three-dimensional (3D) deviation.

\section{Statistical analysis}

The mean and standard deviation values were calculated for each group in each test. Data were explored for normality using Shapiro-Wilk test. The Schuirmann test, a two-one sided test (TOST), was used to assess the equivalence (trueness) between the test groups and the reference scan. A $95 \%$ confidence interval of $0.1 \mathrm{~mm}(100 \mu \mathrm{m})$ [8] and $0.1^{\circ}$ was set. The analysis of variance (ANOVA) and the Tukey's test were used to compare the differences (precision) between groups A, B and C. The significance level was set at $P \leq 0.05$. All the statistical analysis was performed with the SAS 9.4 software (SAS Institute, Cary, NC, USA). 

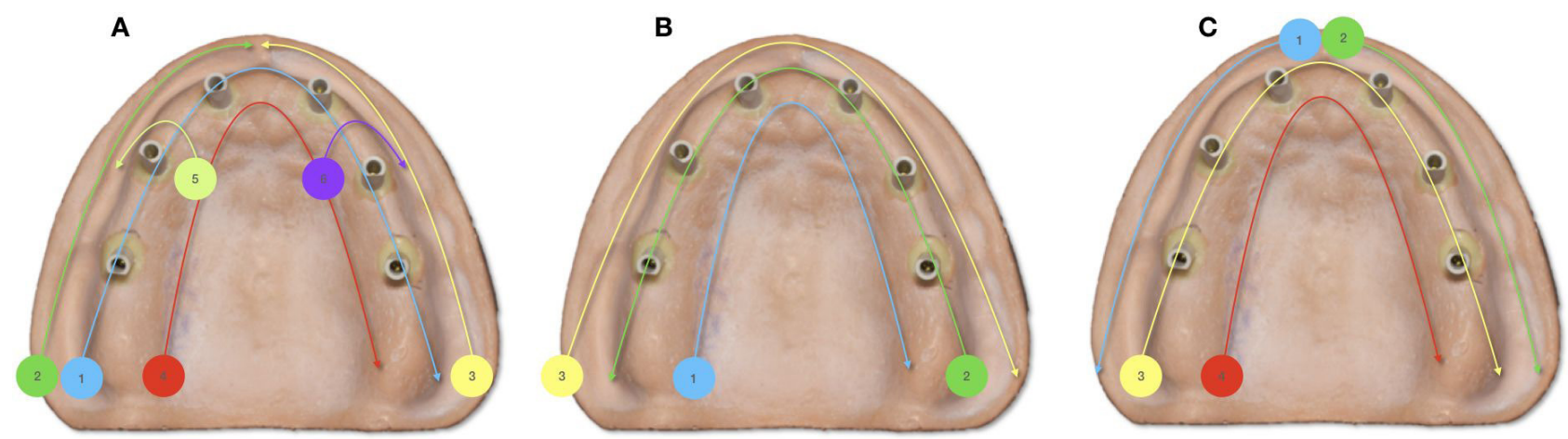

Figure 1 - Graphic representation of scan strategies A, B and C.
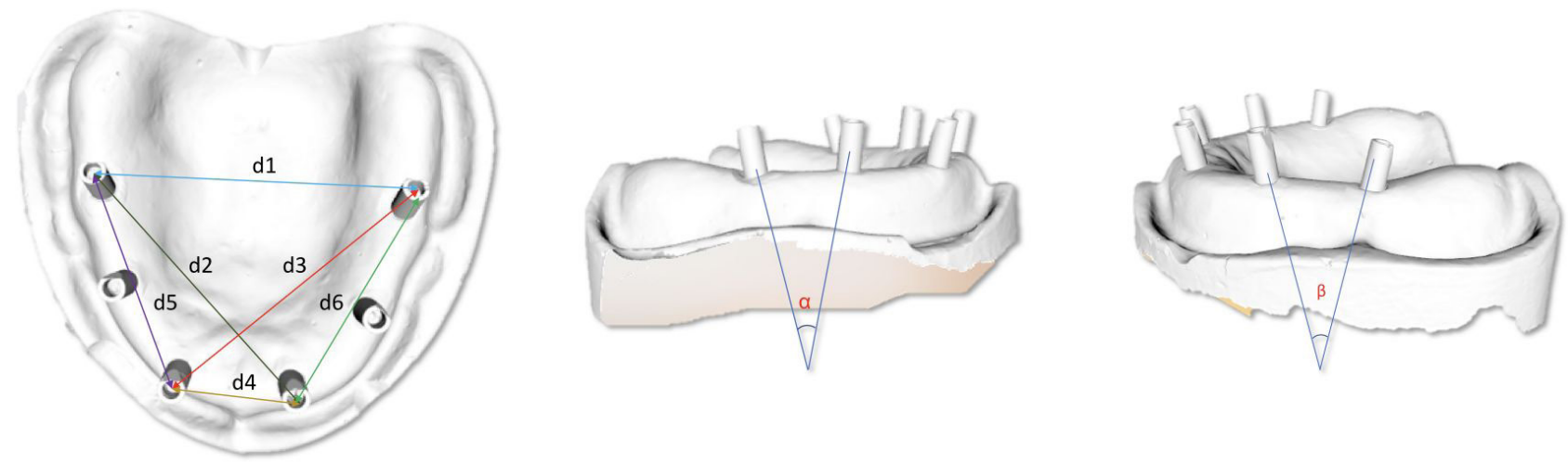

Figure 2 - Determination of measuring points $(d 1, d 2, d 3, d 4, d 5, d 6, \alpha$ and $\beta)$.

\section{RESULTS}

Tables I and II show the mean, standard deviation and confidence interval from the experimental scans for linear and angular distances, in millimeters and degree respectively.

\section{Equivalence test (trueness)}

Figure 3 shows the values of 3D deviations from the experimental scans to the reference scan for all linear distances. All linear distances presented equivalence $[\mathrm{p}<0.01]$ to those found on the reference scan for all scan strategies. All scan strategies presented a tendency of negative means for linear distances except for d4 in strategy C $(0.001 \pm 0.01)$.

Figure 4 shows the values of 3D deviations from the experimental scans to the reference scan for all angular distances. All angular distances did not present equivalence $[p=0.05]$ to those found on the reference scan. For the alpha angle, strategies A $(-0.04 \pm 0.27)$ and B $(-0.28 \pm 0.50)$ presented a tendency of negative means while strategy C $(0.12 \pm 0.51)$ presented a tendency of positive means. Strategy A presented the lowest mean and standard deviation values while strategy $B$ the highest one. For the beta angle, all strategies presented a tendency of negative means. Strategy B $(-0.24 \pm 0.28)$ presented the lowest mean and standard deviation values, strategy A $(-0.39 \pm 0.35)$ the highest one and strategy $\mathrm{C}$ presented mean and standard deviation of $0.30 \pm 0.32$.

\section{Repeatability test (precision)}

Figure 5 shows the absolute values of 3D deviations from the experimental scans to the reference scan for all linear distances. Significant 3D deviations $[\mathrm{p}<0.05]$ were found between strategy $\mathrm{B}(0.02 \pm 0.01)^{\mathrm{b}}$ and $\mathrm{C}(0.05 \pm 0.04)^{\mathrm{a}}$ for $\mathrm{d} 1$. There was no significant difference between strategies $\mathrm{A}$ $(0.03 \pm 0.02)^{\mathrm{ab}}$ and $\mathrm{B}(0.02 \pm 0.01)^{\mathrm{b}}$ and strategies A $(0.03 \pm 0.02)^{\mathrm{ab}}$ and $C(0.05 \pm 0.04)^{\mathrm{a}}$. In all other linear (d2, d3, d4, d5 and d6) and angular ( $\alpha$ and $\beta$ ) distances no statistically significant difference was found between strategies A, B and C. Figure 6 shows the absolute values of 3D deviations from the experimental scans to the reference scan for all angular distances. 
Table I - Mean, standard deviation and confidence interval from the experimental scans for linear distances (in mm)

\begin{tabular}{|c|c|c|c|c|c|c|c|c|c|c|c|c|}
\hline \multirow{2}{*}{$\begin{array}{c}\text { Scan } \\
\text { Strategyy }\end{array}$} & \multirow{2}{*}{ mean } & \multirow{2}{*}{$\begin{array}{l}\text { std } \\
\text { dev }\end{array}$} & \multicolumn{2}{|c|}{$\begin{array}{c}\text { confidence } \\
\text { interval }\end{array}$} & \multirow{2}{*}{ mean } & \multirow{2}{*}{$\begin{array}{l}\text { std } \\
\text { dev }\end{array}$} & \multicolumn{2}{|c|}{$\begin{array}{c}\text { confidence } \\
\text { interval }\end{array}$} & \multirow{2}{*}{ mean } & \multirow{2}{*}{$\begin{array}{l}\text { std } \\
\text { dev }\end{array}$} & \multicolumn{2}{|c|}{$\begin{array}{c}\text { confidence } \\
\text { interval }\end{array}$} \\
\hline & & & $\begin{array}{l}\text { lower } \\
\text { bound }\end{array}$ & $\begin{array}{l}\text { upper } \\
\text { bound }\end{array}$ & & & $\begin{array}{l}\text { lower } \\
\text { bound }\end{array}$ & $\begin{array}{l}\text { upper } \\
\text { bound }\end{array}$ & & & $\begin{array}{l}\text { lower } \\
\text { bound }\end{array}$ & $\begin{array}{l}\text { upper } \\
\text { bound }\end{array}$ \\
\hline & \multicolumn{4}{|c|}{ D1 } & \multicolumn{4}{|c|}{ D2 } & \multicolumn{4}{|c|}{ D3 } \\
\hline A & -0.007 & 0.032 & -0.030 & 0.016 & -0.021 & 0.019 & -0.035 & -0.007 & -0.015 & 0.026 & -0.033 & 0.003 \\
\hline B & -0.009 & 0.020 & -0.024 & 0.006 & -0.038 & 0.032 & -0.061 & -0.016 & -0.016 & 0.017 & -0.028 & -0.003 \\
\hline \multirow[t]{2}{*}{$C$} & -0.022 & 0.059 & -0.065 & 0.020 & -0.008 & 0.029 & -0.029 & 0.012 & -0.014 & 0.039 & -0.042 & 0.014 \\
\hline & \multicolumn{4}{|c|}{ D4 } & \multicolumn{4}{|c|}{ D5 } & \multicolumn{4}{|c|}{ D6 } \\
\hline A & -0.003 & 0.017 & -0.015 & 0.010 & -0.019 & 0.023 & -0.036 & -0.002 & -0.021 & 0.022 & -0.036 & -0.005 \\
\hline B & -0.005 & 0.016 & -0.017 & 0.007 & -0.020 & 0.014 & -0.030 & -0.010 & -0.042 & 0.032 & -0.064 & -0.019 \\
\hline C & 0.001 & 0.017 & -0.011 & 0.014 & -0.005 & 0.021 & -0.020 & 0.010 & -0.014 & 0.021 & -0.030 & 0.001 \\
\hline
\end{tabular}

Table II - Mean, standard deviation and confidence interval from the experimental scans for angular distances (in degrees)

\begin{tabular}{cccccccccc}
$\begin{array}{c}\text { Scan } \\
\text { Strategy }\end{array}$ & mean & std dev & $\begin{array}{c}\text { confidence interval } \\
\text { lower } \\
\text { bound }\end{array}$ & $\begin{array}{c}\text { upper } \\
\text { bound }\end{array}$ & mean & std dev & \multicolumn{3}{c}{$\begin{array}{c}\text { confidence interval } \\
\text { lower } \\
\text { bound }\end{array}$} \\
upper \\
bound
\end{tabular}

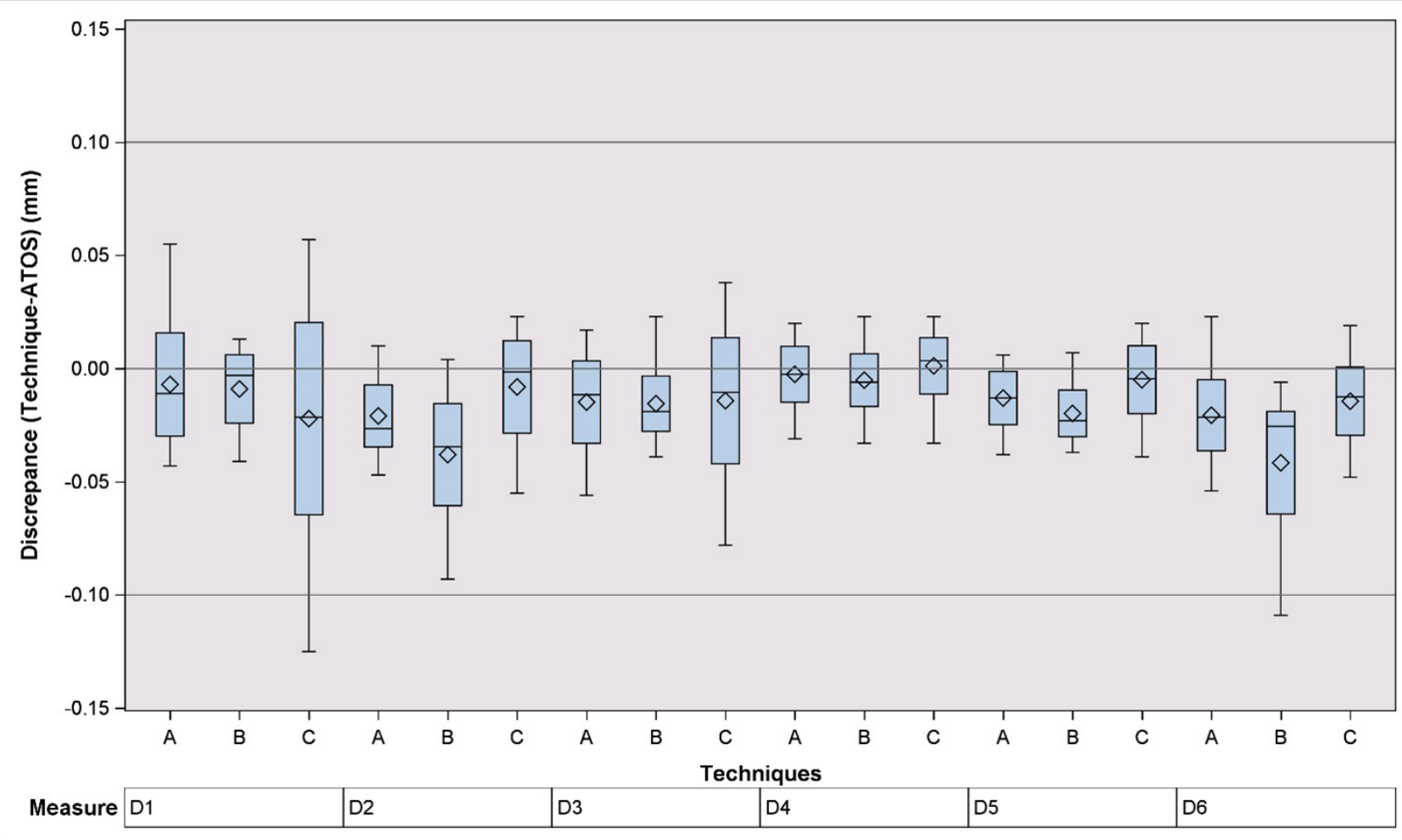

Figure 3 - 3-D deviations values from the experimental scans to the reference scan (in $\mathrm{mm}$ ). 


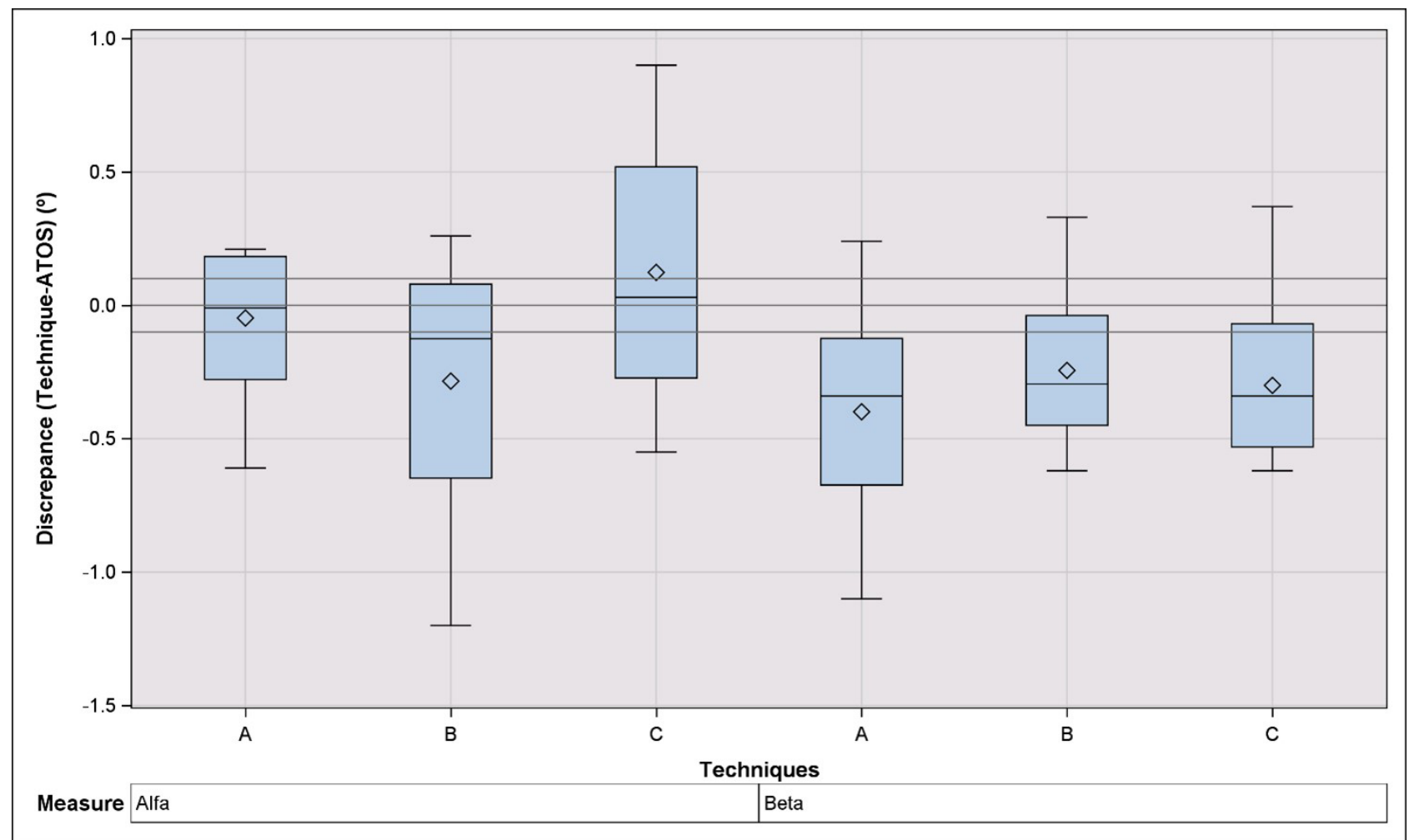

Figure 4 - 3-D deviations values from the experimental scans to the reference scan (in degrees).

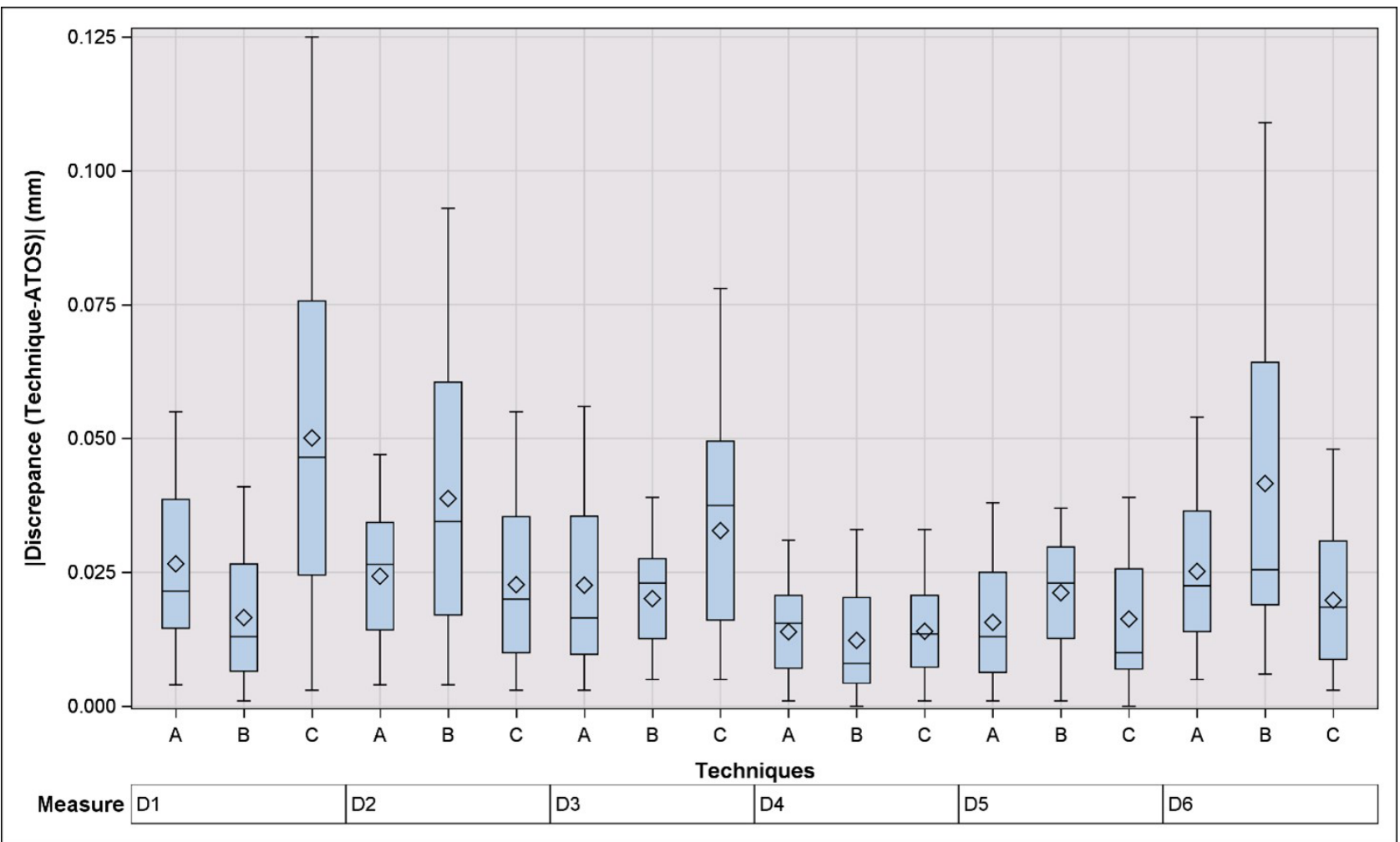

Figure 5 - Absolute values of 3-D deviations from the experimental scans to the reference scan (in $\mathrm{mm}$ ).

\section{DISCUSSION}

The aim of this study was to compare the accuracy of three different scan strategies and the influence of implant angulation for full-arch multiple implant using the Primescan IOS. The null hypothesis was not rejected.

The reference scanner (ATOS Core 80) is an industrial structured blue light 3D scanner, 


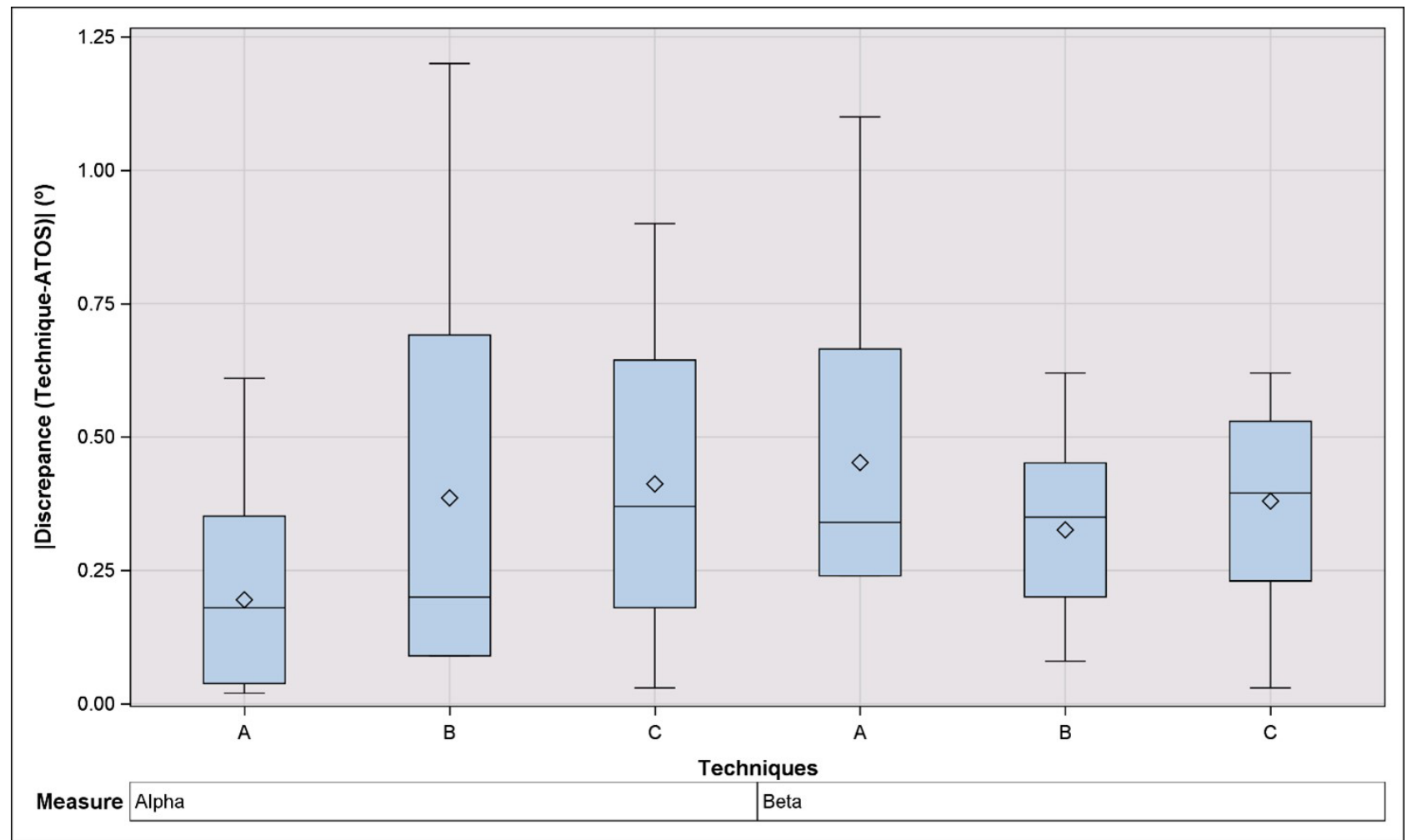

Figure 6 - Absolute values of 3-D deviations from the experimental scans to the reference scan (in degrees).

complies with ISO 12836 and shows accuracy up to $3 \mu \mathrm{m}$, with a precision of $2 \mu \mathrm{m}$ for jaw-sized scans [9-11]. A sample size of 10 scans for each scanning strategy has been demonstrated as sufficient to obtain consistent statistical results by several authors [11-16].

Some published reports have evaluated the scan strategy in complete-arch scanning and digital intraoral scanning $[7,11,17,18]$ However, there is still a lack of studies that evaluate the scan strategy in full-arch multiple implant scan [6,19-21]. To the knowledge of the authors, this is the first study using the CEREC Primescan to evaluate the impact of different scan strategies and implant angulation on scan accuracy in full arch multiple implant impression. There are no other studies using the same measuring method. Thus, the lack of available literature makes it difficult to compare the results obtained in this study.

Although a study [22] using a $0.4^{\circ}$ as an acceptable angle deviation between implants was found, the clinically acceptable threshold for the angle deviations is not yet defined in the literature [4]. In the present study a confidence interval of $0,1^{\circ}$ was set. The statistical analysis suggest that equivalence would be achieved if a $0.5^{\circ}$ confidence interval was set for all strategies.
An in vitro study investigated the trueness and precision under repeatable conditions for different IOSs (Trios 3, Trios 3 Mono and Itero Element) when scanning fully edentulous arch with multiple implants and reported that precision is low for the tested IOS devices [19]. A more recent in vitro study evaluated the accuracy of digital complete-arch edentulous implant scanning and the influence of the different extents of surrounding movable soft tissue and reported that the accuracy of the IOSs tested (Trios 3, Trios Color, CEREC Omnicam and CEREC Primescan) was comparable with that of the conventional impression technique and that the amount of flexible soft tissue interference affected the accuracy of the digital scans [21].

This is an in vitro study where clinical conditions that could compromise the results of the scanning process such as presence of saliva, tongue, cheek, limited mouth opening and patient movement have not been evaluated. Although there wasn't statistical significance difference between strategies A, B and C, strategy B should be preferred in clinical practice since has fewer steps. Further in vivo studies should be conducted to validate the accuracy of this IOS device under clinical conditions. 


\section{CONCLUSION}

Within the limitations of this in vitro study, the following conclusions were drawn:

1- There was no statistically significant difference between strategies A, B and C except for $\mathrm{d} 1$ in strategy $\mathrm{B}$ and $\mathrm{C}$;

2- Implant angulation did not affect the accuracy of the CEREC Primescan IOS.

\section{Acknowledgments}

The authors thank the University of São Paulo for all the support.

\section{Conflict of Interest}

The authors declare no conflicts of interest.

\section{Funding}

This research did not receive any specific grant from funding agencies in the public, commercial, or not-for-profit sectors.

\section{Regulatory Statement}

This study was conducted in accordance with all the provisions of the local human subjects oversight committee guidelines and policies:

The research was conducted "in vitro" and did not involve any humans or animals, therefore, there was no need for registration and ethic control.

\section{REFERENCES}

1. Mangano F, Gandolfi A, Luongo G, Logozzo S. Intraoral scanners in dentistry: a review of the current literature. BMC Oral Health. 2017;17(1):149. http://dx.doi.org/10.1186/s12903-017-0442-x. PMid:29233132

2. Kachhara S, Nallaswamy D, Ganapathy DM, Sivaswamy V, Rajaraman V. Assessment of intraoral scanning technology for multiple implant impressions - A systematic review and metaanalysis. J Indian Prosthodont Soc. 2020;20(2):141-52.. http:// dx.doi.org/10.4103/jips.jips_379_19. PMid:32655218.

3. Bohner L, Gamba DD, Hanisch M, Marcio BS, Tortamano Neto P, Laganá DC, et al. Accuracy of digital technologies for the scanning of facial, skeletal, and intraoral tissues: a systematic review. J Prosthet Dent. 2019;121(2):246-51. http://dx.doi. org/10.1016/j.prosdent.2018.01.015. PMid:30017156

4. Abduo J, Elseyoufi M. Accuracy of intraoral scanners: a systematic review of influencing factors. Eur J Prosthodont Restor Dent. 2018;26(3):101-21. http://dx.doi.org/10.1922/ EJPRD_01752Abduo21. PMid:29989757.

5. Imburgia M, Kois J, Marino E, Lerner H, Mangano FG. Continuous Scan Strategy (CSS): A novel technique to improve the accuracy of intraoral digital impressions. Eur J Prosthodont Restor Dent. 2020;28(3):128-41. http://dx.doi.org/10.1922/ EJPRD_2105Imburgia14. PMid:32750237.

6. Mutwalli H, Braian M, Mahmood D, Larsson C. Trueness and precision of three-dimensional digitizing intraoral devices. Int J Dent. 2018;5189761. http://dx.doi.org/10.1155/2018/5189761. PMid:30598665

7. Passos L, Meiga S, Brigagão V, Street A. Impact of different scanning strategies on the accuracy of two current intraoral scanning systems in complete-arch impressions: an in vitro study. Int J Comput Dent. 2019;22(4):307-19. PMid:31840139.

8. Svanborg P, Skjerven H, Carlsson P, Eliasson A, Karlsson S, Ortorp A. Marginal and internal fit of cobalt-chromium fixed dental prostheses generated from digital and conventional impressions. Int J Dent. 2014;2014:534382. http://dx.doi. org/10.1155/2014/534382. PMid:24723954

9. Dold P, Bone MC, Flohr M, Preuss R, Joyce TJ, Deehan D, et al. Validation of an optical system to measure acetabular shell deformation in cadavers. Proc Inst Mech Eng H. 2014;228(8):781-6.; published online Aug 1, 2014. http://dx.doi. org/10.1177/0954411914546562. PMid:25085696.

10. Renne W, Ludlow M, Fryml J, Schurch Z, Mennito A, Kessler $R$, et al. Evaluation of the accuracy of 7 digital scanners: an in vitro analysis based on 3-dimensional comparisons. J Prosthet Dent. 2017;118(1):36-42. http://dx.doi.org/10.1016/j. prosdent.2016.09.024. PMid:28024822.

11. Medina-Sotomayor P, Pascual-Moscardó A, Camps I. Accuracy of four digital scanners according to scanning strategy in completearch impressions. PLoS One. 2018;13(9):e0202916. http://dx.doi. org/10.1371/journal.pone.0202916. PMid:30212498.

12. Rhee YK, Huh YH, Cho LR, Park CJ. Comparison of intraoral scanning and conventional impression techniques using 3-dimensional superimposition. J Adv Prosthodont. 2015;7(6):460-7. http:// dx.doi.org/10.4047/jap.2015.7.6.460. PMid:26816576.

13. González de Villaumbrosia P, Martínez-Rus F, GarcíaOrejas A, Salido MP, Pradíes G. In vitro comparison of the accuracy (trueness and precision) of six extraoral dental scanners with different scanning technologies. J Prosthet Dent. 2016;116(4):543-550.e1. http://dx.doi.org/10.1016/j. prosdent.2016.01.025. PMid:27112413

14. Serag M, Nassar TA, Avondoglio D, Weiner S. A comparative study of the accuracy of dies made from digital intraoral scanning vs. elastic impressions: an in vitro study. J Prosthodont. 2018;27(1):8893. http://dx.doi.org/10.1111/jopr.12481. PMid:27149542.

15. Medina-Sotomayor P, Pascual-Moscardó A, Camps I. Relationship between resolution and accuracy of four intraoral scanners in complete-arch impressions. J Clin Exp Dent. 2018;10(4):e361-6. http://dx.doi.org/10.4317/jced.54670. PMid:29750097

16. Kim JE, Amelya A, Shin Y, Shim JS. Accuracy of intraoral digital impressions using an artificial landmark. J Prosthet Dent. 2017;117(6):755-61. http://dx.doi.org/10.1016/j. prosdent.2016.09.016. PMid:27863856.

17. Müller P, Ender A, Joda T, Katsoulis J. Impact of digital intraoral scan strategies on the impression accuracy using the TRIOS Pod scanner. Quintessence Int. 2016;47(4):343-9. http://dx.doi. org/10.3290/j.qi.a35524. PMid:26824085

18. Oh KC, Park JM, Moon HS. Effects of scanning strategy and scanner type on the accuracy of intraoral scans: a new approach for assessing the accuracy of scanned data. J Prosthodont. 2020;29(6):518-23. http://dx.doi.org/10.1111/jopr.13158. PMid:32133690

19. Rutkūnas V, Gečiauskaitè A, Jegelevičius D, Vaitiekūnas M. Accuracy of digital implant impressions with intraoral scanners. A systematic review. Eur J Oral Implantol. 2017;10(Suppl 1):101-20. PMid:28944372.

20. Motel C, Kirchner E, Adler W, Wichmann M, Matta RE. Impact of different scan bodies and scan strategies on the accuracy of digital implant impressions assessed with an intraoral scanner: an in vitro study. J Prosthodont. 2020;29(4):309-14. http://dx.doi. org/10.1111/jopr.13131. PMid:31802574 
21. Knechtle N, Wiedemeier D, Mehl A, Ender A. Accuracy of digital complete-arch, multi-implant scans made in the edentulous jaw with gingival movement simulation: an in vitro study. J Prosthet Dent. 2021 Feb 18:S0022-3913(21)00019-6. PMID: 33612335
22. Andriessen FS, Rijkens DR, van der Meer WJ, Wismeijer DW. Applicability and accuracy of an intraoral scanner for scanning multiple implants in edentulous mandibles: a pilot study. J Prosthet Dent. 2014;111(3):186-94. http://dx.doi.org/10.1016/j. prosdent.2013.07.010. PMid:24210732

\section{Danilo de Melo Lopes}

(Corresponding address)

Universidade de São Paulo, School of Dentistry, Department of Prosthodontics,

São Paulo, SP, Brazil.

Email: danilomelolopes@hotmail.com

Date submitted: 2021 April 30

Accept submission: 2021 August 05 